\title{
MENCERMATI TEOLOGI REFORMED DAN GERAKAN REFORMED INJILI
}

\author{
Hadi P. Sahardjo \\ STTT SAPPI Ciranjang \\ hadipsahardjo@gmail.com
}

\begin{abstract}
The development of Reformed doctrine and theology, which has been going on for more than five centuries, has been a milestone in the history of the church and Christianity. It must be acknowledged that the Reformation Movement has been evidence that God is still using His chosen people to straighten out the teachings and doctrines that the church was at that time. Names such as: Martin Luther, Phillip Melanchthon, Ulrich Zwingli, Johannes Calvin, and others are listed as reformers in the Calvinist tradition. God created, but the chosen man has been made the enforcer of the truth of the word to be echoed.
\end{abstract}

KeyPhrases: doctrine, Reformed, straightened teaching, distorted, truth enforcement.

\section{ABSTRAK}

Perkembangan doktrin dan Teologi Reformed yang sudah berlangsung lebih dari lima abad, telah menjadi sebuah tonggak sejarah dalam sejarah gereja dan kekristenan. Harus diakui bahwa Gerakan Reformasi telah menjadi bukti bahwa Tuhan masih memakai orang-orang yang dipilih-Nya untuk meluruskan pengajaran dan doktrin-doktrin yang sudah diselewengkan oleh gereja pada saat itu. Nama-nama seperti: Martin Luther, Phillip Melanchthon, Ulrich Zwingli, Johannes Calvin, dan lain-lain tercatat sebagai reformator dalam tradisi Calvinis. Tuhan berkarya, tetapi manusia terpilih telah dijadikan sebagai penegak kebenaran firman yang harus dikumandangkan.

FrasaKuci: doktrin, Reformed, meluruskan pengajaran, diselewengkan, penegakkebenaran.

\section{PENDAHULUAN}

Sebenarnya judul atau titel di atas tidak hendak membahas tentang teologi Reforme dan-sich. Karena sesungguhnya tanpa menuliskan pun kita akan dengan mudah menemukan buku-buku teologi Reformed yang ada di perpustakaan- 
perpustakaan seminari atau sekolah teologi maupun di toko-toko buku Kristen. Oleh karena itu tulisan ini akan lebih banyak menyoal tentang berbagai implikasi praktis dari teologi Reformed terhadap pelayanan pada masa-masa setelah reformasi dan kini oleh beberapa tokoh, baik pengkhotbah maupun para penulis atau teolog.

Berbicara mengenai reformasi, tentu tidak akan pernah lepas dari penyebutan tokoh-tokoh pentingnya yakni Martin Luther(1483-1546), Phillip Melanchthon (1497-1560) reformator dalam tradisi Lutheran, serta Ulrich Zwingli (1454-1531) dan Johannes Calvin (1509-1564) reformator dalam tradisi Calvinis. Tetapi di antara mereka, dan sejumlah nama lain yang sangat erat kaitannya dengan reformasi, Martin Luther dan John Calvin adalah nama-nama yang paling populer yang selalu dikaitkan dengan reformasi. Martin Luther untuk kaum Lutheran, dan sebaliknya kalau berbicara mengenai tradisi dan teologi Reformed, pasti mengacu pada nama Calvin. Karena pada hakikatnya ketika kita menyebut nama Calvin, maka dalam benak kita akan muncul pemahaman tentang teologi Reformed. Sehingga penyebutan istilah Calvinis dan Reformed sering dipertukartempatkan, meskipun tidak sepenuhnya benar demikian. Bahkan banyak kalangan gereja beraliran Calvinis yang tidak merasa perlu menyebut diri mereka Reformed. Tetapi jika kita menyebut tentang reformasi yang dikaitkan dengan Hari Reformasi (31 Oktober 1517) pastilah nama Martin Luther yang pertama kali harus disebut. Berkaitan dengan hal ini biarlah penulis lain yang membahasnya. Itulah sebabnya dalam tulisan ini tidak hendak membahas tentang tokoh-tokoh dimaksud, tetapi lebih pada soal pemahaman yang fundamental tentang teologi, atau lebih tepatnya "roh" reformasi dalam teologi Reformed yang berdampak terhadap pelayanan para pelayanTuban sejak era itu hingga kini. Memang, jika berbicara tentang Reformed, maka mau tak mau akan langsung dikaitkan dengan nama Calvin, dengan the Five Points of Calvin dengan TULIPnya; dengan trisolanya, dengan pengajaran predestinasinya, dsb.Patutdisayangkan, di tengah maraknya dunia kekristenan yang sedang hangat menyambut $500^{\text {th }}$ Church Reformation yang dicanangkan Martin Luther, Jerman sebagai tempat lahirnya reformasi pada tanggal 31 Oktober 1517, tetapi sayang, justru pada tanggal 1 Juli 2017 Jerman telah melegalkan perkawinan sejenis, ${ }^{1}$ hal yang sangat dilarang oleh Alkitab.

${ }^{1}$ Siaran Radio BBC, 1 Juli 2017. 


\section{METODOLOGI}

Penulisan ini mendasarkan pada penggunaan metode kajian pustaka yang bersumber dari buku-buku terkait dengan teologi reformed dan observasi terhadap perkembangan faham reformed (dan) injili sebagaimana berkembang pada akhir-akhir ini. Pembahasan diarahkan pada dinamika perkembangan Teologi Reformed yang sudah memengaruhi beberapa aliran dalam gereja-gereja maupun sekolah-sekolah teologi yang semula hanya mengenal istilah "Injili" namun yang di kemudian hari menyematkan label reformed atau Reformed Injili. Sebagaimana diketahui bahwa gereja maupun sekolah teologi yang mengenalkan diri sebagai "Injili" itu semula bertujuan "sekedar" sebagai pembeda dengan aliranaliran yang bernuansa Pentakosta/Kharismatik, dan di sisi lain sebagai pembeda dengan gereja-gereja dan sekolah-sekolah teologi arus utama atau ekumenikal, yang kadangkala malah menyebuknya sebagai "liberal." Kajian ini mencoba untuk menguak isu-isu dimaksud.

\section{TENTANG TEOlogi Reformed}

Sebenarnya pada awalnya yang disebut teologi Reformed itu dimulai oleh Zwingli-yang lahir jauh hari sebelum Calvin-yang bertitik tolak pada kebergantungan manusia yang secara radikal terhadap Allah yang berdaulat dan beranugerah, yang dikaburkan oleh sisa-sisa dari ide-ide filosofis humanis. Sementara Calvin adalah seorang pemikir yang lebih sistematik, dan teolog yang sangat biblikal dan praktis, sehingga iman Reformed tersebar ke berbagai belahan Eropa (Bavinck 2014:207).

Dalam bukunya yang berjudul "Pengantar Ke Dalam Teologi Reformed" Yakub Susabda secara singkat merumuskan bahwa teologi Reformed adalah "teologi Alkitab yang ditemukan kembali" (Susabda 2001:3) Ini berarti Teologi Reformed adalah teologi sebagaimana diimani oleh orang Kristen yang mula-mula yang berdasar dan bersumber pada Alkitab, firman Allah yang hidup sebagaimana dipercayai dan diberitakan oleh para rasul Yesus Kristus. Itulah pengajaran yang dilandasi oleh pengakuan-pengakuaniman Reformed, yang menyingkapkan pemahaman teologi Reformed yang sejati. Lebih lanjut Yakub Susabda mengatakan bahwa teologi Reformed yang sejati adalah:

"Teologi John Calvin yang telah diintegrasikan dengan pemikiranpemikiran teologi para teolog Reformator lainnya. (2) teologi yang telah diformulasikan oleh John Calvin berdasarkan beberapa basic premis yang 
konsisten dengan Alkitab. (3) teologi John Calvin telah menemukan aktualisasinya dalam perubahan-perubahan tantangan gereja sepanjang zaman, dan (4) teologi yang dimanifestasikan pengaktualisasian iman Reformed ortodoks dalam integrasinya dengan semangat doktrinalis, kulturalis dan pietis-revivalis zaman ini (Susabda 2001:5-6)."

Dengan kata lain, Teologi Reformed tidak mungkin menafikan seorang Calvin dengan The Five Points of Calvinism-nyasebagaisalah satu pilar utama teologi Reformed, atau yang dikenal dengan istilah TULIP, yang merupakan akronim dari Total Depravity (kerusakan total atau ketidakmampuan total); Uncondition Election (pemilihan tanpa syarat); Limited Atonement (Penebusan Terbatas); Irresistible Grace (Anugerah yang tidak dapat ditolak) dan Perseverence of the Saints (Ketekunan orang-orang Kudus) (Baan 2009). Tetapi Lorraine Boettner lebih suka memakai istilah TULEP yang dinilainya lebih rasional, yaitu singkatan dari Total Inability (Ketidakberdayaan atau ketidakmampuan total); Uncondtion Election (pemilihan tanpa syarat); Limited Atonement (Penebusan terbatas); Efficacious Grace (Anugerah yang Mujarab) dan Perseverence of he Saints (Ketekunan orang-orang kudus) (Boettner 1932). Yakub Susabda menyimpulkan, bahwa teologi Reformed "yang sejati" adalah teologi Reformed dengan semangat "Injili" (Boettner 1932). Apa artinya? Jika kita berbicara tentang teologi Reformed, berarti kita sedang berbicara tentang teologi Injili.

\section{MANA YANG BENAR: REFORMED, INJILI, REFORMED-INJILI}

Banyak teolog yang masih berdebat seputar istilah yang paling tepat untuk menunjukkan faham atau aliran teologi yang paling menunjukkan "kesetiaan"nya pada doktrin dan pengajaran yang murni yang berdasarkan Alkitab, firman Tuhan. Kalau kita kembali pada prinsip dan semangat dasar tercetusnya reformasi oleh Martin Luther yang back to the Bible, kembali kepada Alkitab, pengajaran yang tidak menyimpang dari maksud asli Alkitab, yaitu pengajaran yang yang secara murni mendasarkan pada Alkitab sebagaimana adanya, maka itu adalah kaum Reformed. Yang menjadi pendulumnya pastilah tri-sola (Sola Fide, Sola Gratia dan Sola Scriptura) serta Sola Christo (Solus Christus) dan Soli Deo Gloria serta TULIPnya Calvin. Sehingga selama pengajaran dan doktrin serta pemahaman teologi gereja itu dibingkai dengan "sola-sola” itu, Sola Fide (Hanya oleh Iman); Sola Gratia (Hanya oleh Anugerah); Sola Scriptura (Hanya oleh Alkitab) dan Solus Christus (Hanya oleh Kristus) serta Soli Deo Gloria (Kemuliaan Hanya bagi Allah), menurut penulis itu adalah penerus Reformed. Kelompok yang kembali dan 
berpegang pada prinsip dasar kekristenan yang berdasar dan mengakar pada Alkitab. Bukankah itu yang diajarkan dalam semua aliran Reformed, Injili, Reformed-Injili, Calvinisme serta aliran Konservatisme yang ingin kembali kepada pengajaran yang murni? Bahkan sekarang di Jakarta sudah muncul gereja (kalau boleh dikatakan sebagai aliran baru), yaitu Gereja Reformed Kharismatik. Gereja ini ingin mereformedkan kharismatik dan mengarismatikkan Reformed. Mengapa? Karena mereka melihat ada celah kekurangan baik dalam Pengajaran Reformed maupun aliran Kharismatik. Di Bandung juga ad agereja yang bernama Gereja Puritan Reformed Indonesia (GPRI). Kebetulan, secara pribadi, penulis mengenal pendiri kedua gereja itu. Apakah ini bias dibilang lebih Reformed dan lebih Injili? Atau bahkan dikatakan sesat? Tentu tidak semudah itu untuk menjustifikasinya. Oleh karena pada dasarnya gereja-gereja itu sebenarnya berupaya untuk "mengembalikan" apa yang dinilainya masih kurang dari gerejagereja yang ada sebelumnya. Meskipun harus diakui bahwa seringkali akibat adanya perbedaan-bukan karena soal teologi atau pengajaran, tetapi persoalan individu — sehingga muncul satu gereja baru, tapi semuanya sama, hanya nama yang berbeda. Sekali lagi, pengujian terhadap benar tidaknya sebuah aliran atau faham dalam bergereja dan berteologi, harus difilter dengan apa dan siapa yang menjadi dasar. Teologi yang benar pasti mendasarkan pengajarannya pada fondasi yang benar-benar benar, yaitu Allah Tritunggal sebagaimana disaksikan oleh firman Allah dalam terang Roh Kudus, sebagaimana diimani oleh para murid, oleh orang-orang Kristen mula-mula, oleh para Bapa Gereja, oleh para reformator, maka itu adalah iman dan teologi Reformed yang tidak perlu diperdebatkan.

\section{PandANGAN-PANDANGAN CALVINISME Yang MEMERTAJAM PEMAHAMAN REFORMED}

Kalau mau diringkaskan dari keseluruhan pengajaran Calvin, sebenarnya bias diwakili hanya dengan tiga hal penting: pembenaran, penebusan dan keselamatan. Kedua istilah inilah yang sebenarnya menjadi sentral dari doktrin Calvinis. Inilah yang terangkum dalam makna Sola Gratia dan Sola Fide serta Solus Christus. Yaitu bahwa kita dibenarkan dan diselamatkan hanya oleh karena anugerah semata-mata berdasarkan iman kita ${ }^{2}$ dan atas kasih karunia Tuhan Yesus

${ }^{2}$ Roma 3:28; 5:1; Galatia 3:24. 
Kristus $^{3}$ sebagaimana diajarkan dalam Alkitab sebagai satu-satunya sumber kebenaran yang adalah FirmanTuhan (Sola Scriptura); dan itu semua hanya bagi kemuliaan Allah Bapa (Soli Deo Gloria) dan bukan untuk diri kita sendiri.

Sola Fide

Sejalan dengan Luther dan Zwingli, Calvin mengatakan bahwa iman itu bukan sekedar suatu persetujuan (assenssus), tetapi juga melibatkan pengetahuan (notitia, cognitio) dan kepercayaan (fiducia) (Hall and Liliback 2009:309). Pada saat Abraham dipanggil oleh Tuhan untuk meninggalkan negeri dan kaum keluarganya menuju ke suatu negeri "antah-berantah" yang belum diketahui sama sekali (Kejadian 12). Dikatakan demikian, karena Abraham (masih bernama Abram ketika ia dipanggil Tuhan) benar-benar tidak tahu ke mana dan di mana Tuhan akan memimpinnya. Ini bukan sikap kenekadan Abraham, tetapi sekaligus praktik iman dalam ketiga aspeknya, assenssus, cognitio dan fiducia. Dengan iman dari aspek assenssus jelas, karena Abraham taat secara total terhadap panggilan Tuhan. Tanpa bertanya, langsung merespons "ya" yang ditunjukkan dengan: "Lalu pergilah Abram seperti yang difirmankan TUHAN kepadanya ...” (Kejadian 12:4) yang kembali disaksikan dalam kitab Ibrani, bahwa, "Karena iman Abraham taat, ketika ia dipanggil untuk berangkat ke negeri yang akan diterimanya menjadi milik pusakanya, lalu ia berangkat dengan tidak mengetahui tempat yang ia tuju" (Ibrani 11:8). Kemudian dari aspek cognitio-nya Abraham yang tahu bahwaTuhan adalah Allah yang setia, yang menepati janji-Nya dan tidak akan mengecewakan.

\section{Sola Gratia}

Menurut Anthony Hoekema, ada tujuh momen yang terkait dengan anugerah Allah terhadap manusia, yaitu: Panggilan yang efektif, regenerasi, konversi, pertobatan, iman, pembenaran dan pengudusan (Hoekema 2009:115). Khusus yang berkaitan dengan anugerah keselamatan Allah, dalam sola gratia, ada tiga istilah penting yang tidak boleh dilewatkan, yaitu: justification (pembenaran), redemption (penebusan) dan propitiation (penggantian) (Boice 1993:323).

1.Justification. Ada tiga hal penting yang terkait dengan soal pembenaran (justification). Pertama, dari sisi manusia, pembenaran itu akan terjadi hanya oleh karena iman kita kepada Allah (Roma 3:20, 28; 4:2, 6; 5:1; Galatia 2:16; 3:24).

${ }^{3}$ Roma 3:24; 5:1,9; 1 Korintus 6:11; 2Korintus 5:21; Galatia 2:17; 1Timotius 3:16; Titus 3:7. 
Kedua, dari sisi Allah, itu adalah oleh karena kasih karunia Allah (Roma 3:24; 2 Korintus 5:21; Titus 3:7). Ketiga dari sisi Yesus Kristus, itu adalah berkat pengurbanan darah Kristus (Roma 5:9; 1 Korintus 6:11; Galatia 2:17; 3:11-13) yang kita peroleh melalui iman kita kepada-Nya. Iman seperti inilah yang disebut pistis, iman yang menyelamatkan atau fides salvifica, (Markus 1:15; Yohanes 3:16; 17:3; Roma 3:22; Galatia 2:20; 3:26, dll.) (Bavinck 2014:691); dan bukan sekedar fiducia, atau trust atau kepercayaan saja (Bavinck 2014:692).

2.Redemption, (to redeem, redeemer) yang berarti: penebusan, membebaskan, melepaskan, menyelamatkan, mengampuni. Menurut Boice, juga bias dipakai terhadap seseorang yang dipenjara kemudian mendapat kebebasannya, seperti seorang terpidana yang mendapatkan pembebasannya, a prisoner became free (Boice 1993:323).

Berhubungan dengan makna penebusan (redemption), Alkitab secara langsung menyebutkan dengan jelas bahwa penebusan dosa itu hanya terjadi oleh karena kasih Allah Bapa (Yohanes 3:16) melalui pengurbanan darah Tuhan Yesus Kristus. Sebab "tanpa penumpahan darah tidak ada pengampunan (Ibrani 9:22; 13:20); dan bahwa "darah Yesus, Anak-Nya itu menyucikan kita dari segala dosa" (1Yohanes 1:7) dan itu dilakukan oleh TuhanYesus ketika Dia mati di atas kayu salib (Kisah 5:30; 10:39; Filipi 2:8; Kolose 2:14; 1 Petrus 2:24).

3.Penggantian (propitiation). Dalam suratnya, rasul Petrus menjelaskan makna penggantian ini secara lugas dikatakan ketika dia menuliskan demikian:

"Sebab juga Kristus telah mati sekali untuk segala dosa kita, Ia yang benar untuk orang-orang yang tidak benar, supaya Ia membawa kita kepada Allah; Ia, yang telah dibunuh dalam keadaan-Nya sebagai manusia, tetapi yang telah dibangkitkan menurut Roh (1 Petrus 3:18)."

Ini pulalah yang dikatakan oleh David Hall yang menggaris bawahi pandangan Calvin tentang pokok ini sebagai berikut:

"Calvin menunjukkan dari Kitab Suci bahwa Kristus mengambil kutuk yang pantas kita dapatkan (Galatia 3:13), membayar hukuman yang layak kita terima (Yesaya 53:5,8), dan memikul dosa-dosa kita (1Petrus 2:24) untuk lebih jauh menekankan bahwa Ia melakukan suatu karya untuk mendapatkan keselamatan kita (Hall and Liliback 2009:259).”

Dengan kata lain, penggantian itu dilakukan oleh Allah Bapa melalui pengurbanan Tuhan Yesus Kristus di atas kayu salib untuk dan karena dosa-dosa kita. 


\section{Sola Scriptura}

John Calvin memberikan dua poin tentang penyataan Allah, yaitu "penyataan Allah dalam alam semesta" dan "penyataan Allah dalam Alkitab" sebagaimana ditulisnya dalam Institusio Bab V dan Bab VI-IX. Di situ dikatakan bahwa manusia dapat mengenal karya dan kebesaran Allah dalam alam ciptaanNya (Calvin 2015:17). Meskipun demikian penyataan Allah dalam Alkitab itu lebih ampuh jika dibandingkan dengan penyataan Allah dalam alam (Calvin 2015:23). Ini disebabkan bahwa melalui Alkitab ini manusia dapat berkomunikasi dengan Allah melalui firman-Nya. Itu pula yang ditandaskan oleh Henry Meeter dalam tulisannya, Pandangan-pandangan Dasar Calvinisme (Meeter 2009:17) yang mencatat bahwa bagi Calvinis, maka sudah seharusnya menjadikan Alkitab itu sebagai kanon yang menjadi pedoman bagi kehidupannya, dalam iman yang membimbing akal budinya serta dalam praktik yang akan menentukan kewajibannya sehari-hari. Itulah sebabnya-sebagaimana telah disebutkan di atas-yaitu penyataan yang pertama dan orisinal lewat melalui alam, atau yang disebutnya sebagai kitab alam (Meeter 2009:17-18). Kedua adalah penyataan Allah dalam Alkitab, atau yang sering kita sebut sebagai penyataan khusus, yang tingkatannya lebih tinggi daripada "kitab alam" karena dengannya alam dapat dikoreksi sehingga tidak terjadi distorsi. Calvin juga mengatakan bahwa kita harus memandang alam dari kacamata Alkitab, yang menjadi dasar yang terutama bagi seluruh wawasan kehidupan Kristen (Meeter 2009:20). Konsep inilah yang kemudian kita kenal sebagai "penyataan umum" (wahyu Allah melalui dan dalam alam semesta) serta "penyataan khusus" yang yang menjadi dasar iman Kristen, yakni Alkitab firman yang tertulis (Bavinck 2014:391). Penyataan khusus ini mencapai puncaknya hanya di dalam pribadi Kristus, Sang Logos, yang menjadi isi sentral dari seluruh penyataan khusus, yaitu Firman yang menjadi daging (Yohanes 1:1-3) (Bavinck 2014:415) sebagaimana biasa dibahas dalam kelas-kelas prolegomena.

Dalam Alkitab baik Perjanjian Lama maupun Perjanjian Baru terdapat istilah-istilah yang menunjuk pada konsep penyataan khusus. Perjanjian Lama memakai istilah galah yang berarti menyibak, disingkapkan, menunjukkan, muncul, dinyatakan (Kejadian 35:7; 1 Samuel 2:27; 3:21; Yesaya 53:1; dll.); rã'äbyang artinya: melihat, dilihat, menunjukkan diri, muncul (Kejadian 12:7; 17:1; $18: 1$ dll.); yãdã', mengetahui, membuat diketahui, mengajar (Bilangan 12:6). Kemudian dalam Perjanjian Baru juga ada beberapa istilah khusus seperti: emfanizein (memanifestasikan diri, membuat diri kelihatan, menunjukkan diri, muncul (Matius 27:53; Yohanes 14:21-22); epifaneia, muncul, yang merujuk pada 
kedatangan-Nya yang kedua kali (2 Tesalonika 2:8; 1 Timotius 6:14; Titus 2:13 dll.). Ini disejajarkan dengan kata apokalouptein (penyingkapan), phaneroun (membuka selubung) di mana Alkitab membuka diri dengan hadirnya Tuhan Yesus yang menyatakan diri-Nya kedalam dunia ini dalam rupa manusia (Bavinck 2014:391-92).

Itulah sebabnya, maka terkait dengan hal tersebut, ada tiga istilah penting dalam Bahasa Latin yang sering dipakai untuk mengekspresikan eksistensi firman Tuhan, yaitu oratorio, lexio dan meditatio. Yang disebut dengan oratio adalah firman yang diucapkan atau yang difirmankan, baik yang difirmankan secara langsung oleh Tuhan kepada umat-Nya, misalnya kepada Adam, Abraham, Ishak dan Yakub, Musa atau kepada para nabi lainnya serta para rasul; maupun yang diucapkan oleh para nabi, khususnya yang merupakan ucapan yang disampaikan kepada umat Allah sebagaimana yang difirmankan dan dikehendaki Allah. Firman Tuhan yang disampaikan oleh para nabi itu biasanya merupakan ucapan langsung yang disertai dengan ungkapan, "Tuhan berfirman ..." atau. "Tuhan Allah berfirman" atau "demikianlah firman Tuhan" dan sebagainya yang biasanya diberi tanda kutip (“...”). Misalnya "TUHAN Allah berfirman: “Tidak baik, kalau manusia itu seorang diri saja. Aku akan menjadikan penolong baginya, yang sepadan dengan dia." (Kejadian 2:18); atau waktu Tuhan memanggil Adam dan Hawa, "Di manakah engkau?" atau ketika Tuhan berfirman kepada Abram: "Pergilah dari negerimu dan dari rumah bapamu ini ke negeri yang akan Kutunjukkan kepadamu..." (Kejadian 12:1). Firman Tuhan kepada Musa ketika Musa dipanggil untuk memimpin bangsa Israel keluar dari tanah Mesir, berfirmanlah Allah kepada Musa: "Beginilah kau katakan kepada orang Israel: TUHAN, Allah nenek moyangmu, Allah Abraham, Allah Ishak dan Allah Yakub, telah mengutus aku kepadamu: itulah nama-Ku untuk selama-lamanya dan itulah sebutan-Ku turun-temurun.” (Keluaran 3:15). Kepada Yesaya Tuhan berfirman, "Siapakah yang akan Kuutus, dan siapakah yang mau pergi untuk aku?" (Yesaya 6:8). Kepada nabi Hosea dia diutus untuk berbicara kepada bangsa Israel, demikian : "Pergilah, kawinilah seorang para sundal dan peranakkanlah anak-anak sundal, karena negeri ini bersundal hebat dengan membelakangi TUHAN." (Hosea1:2) dan masih banyak lagi. Inilah firman yang oratio tadi.

Selanjutnya lexio, atau firman yang tertulis, yaitu firman Allah yang dituliskan, dan itu tertulis dalam Alkitab Perjanjian Lama dan Perjanjian Baru, yang terdiridari 39 pasal dalam Perjanjian Lama dan 27 pasal dalam Perjanjian Baru, sehingga keseluruhannya berjumlah 66 buah kitab, 1189 pasal dan lebih dari 30.000 ayat. Inilah firman yang tertulis, yang dituliskan oleh orang-orang yang 
dikuasai oleh Roh Allah, firman yang diwahyukan atau yang diilhamkan oleh Allah, sebagaimana dikatakan oleh rasul Paulus dalam 2 Timotius 3:16, "Segala tulisan yang diilhamkan Allah memang bermanfaat untuk mengajar, untuk menyatakan kesalahan, untuk memperbaiki kelakuan dan untuk mendidik orang dalam kebenaran. Frasa pasagrap hetheopneustos yang diterjemahkan menjadi "segala tulisan yang diilhamkan Allah" itu dalam berbagai versi dalam bahasa Inggris diterjemahkan dalam pengertian yang sangat mirip, misalnya dalam versi KJV terjemahannya adalah "All scripture is given by inspiration of God" yang dapat diterjemahkan menjadi "Semua kitab adalah diberikan oleh (melalui) inspirasi dari Allah". Lalu dalam New Standard Version (NSV) dikatakan "All Scripture is inspired by God." (Semua kitab adalah diinspirasikan oleh Allah). Selanjutnya dalam New International Version (NIV) malah menerjemahkan frasa itu menjadi, "All Scripture is God-breathed" atau "Semua Kitab adalah dihembuskan/dinafaskan oleh Allah." Dengan kata lain tidak ada satu bagian pun dalamAlkitab ini yang tidak berasal dari wahyu Allah atau yang tidak dinafaskan oleh Allah. Dalam hal ini Alkitab terjemahan Bahasa Indonesia Sehari-hari (BIS) malah cukup lugas, demikian: "Semua yang tertulis dalam Alkitab, diilhami oleh Allah dan berguna untuk mengajarkan yang benar, untuk menegur dan membetulkan yang salah, dan untuk mengajar manusia supaya hidup menurut kemauan Allah.” Berarti seluruh yang tertulis dalam Alkitab itu berasal dari Allah sendiri, melalui tangan orangorang yang telah mendapat wahyu atau inspirasi dari Allah. Ditulis oleh manusia yang memiliki kesadaran penuh tetapi yang dikontrol oleh Roh Kudus. Itulah sebabnya Alkitab itu disebut inerrancy, yang artinya "sudah cukup" sehingga tidak perlu ditambahkan atau dikurangi lagi (Wahyu 22:18,19). Selain itu Alkitab juga bersifat infallibility, tidak bisa salah. Mengapa tidak bisa salah? Jawabannya kembali lagi pada penjelasan di atas, yaitu karena Alkitab diwahyukan atau diilhamkan oleh Allah sendiri melalui orang-orang yang sudah dipilih dan dikuasai oleh Roh Kudus (Mazmur 119:160; Yohanes 17:17).

Tepat sekali yang dikatakan oleh David Wells, dalam bukunya: Keberanian Menjadi Protestan sebagai berikut:

"Apa pun yang ada didalam Kitab Suci itu bersifat otoritatif dan mengikat, batu ujian untuk mengukur diri kita dan menguji setiap klaim. Penuntun bagi manusia untuk hidup di hadapan Allah dengan cara yang menyenangkan-Nya, dan bahwa hanya Alkitab yang menjadi otoritas dalam hidup kita (Wells 2014:254)." 
Oleh karena Alkitab itu berotoritas, maka dengannya doktrin-doktrin Kristen itu berakar, sehingga menjadi satu-satunya sumber khotbah yang juga berotoritas. Sehingga pengajaran di gereja-gereja Kristen tidak hanya bersumber pada sola cultura, tapi harus pada sola Scriptura.

\section{Pengaruh Reformed Dalam PElayanan Dulu Dan Kini}

Tidak bias disangkal bahwa gerakan reformasi dan teologi Reformed ini memiliki pengaruh yang sangat luas dalam berbagai bidang, seperti dalam dunia literatur, pengkhotbah, pendidikan-khususnya pendidikan teologi atau seminari-misi dan penginjilan, dan sebagainya. Beberapa di antaranya yang penulis anggap bias mewakili apa yang dimaksudkan adalah:

\section{Dalam Dunia Literatur}

Dalam dunia literature ada banyak penulis Kristen yang sangat berpengaruh yang dijiwai oleh semangat dan pemikiran Reformed. Bagian ini hanya akan memaparkan beberapa nama dan sebagian karyanya yang berpengaruh dalam pemahaman, pemikiran dan perilaku kekristenan secara tepat dan alkitabiah. Sebut saja misalnya: C.S. Lewis, J.I. Packer, David F. Wells, Steven Lawson, dll.

C.S. Lewis atau Clive Staples Lewis(29 November 1898- 22 November 1963), adalahseorangpenulis dan pakar sastra dariInggris, hidup dalam tradisi Protestan yang ketat. Bukunya yang sangat terkenal adalah Mere Christianity (1952); The Screwtape Letters (1942); The Great Divorce (1945) dan lain-lain yang juga sudah diterjemahkan kedalam Bahasa Indonesia. Meskipun yang ditulis C.S. Lewis kebanyakan bukan buku-buku teologi, bahkan beberapa diantaranya buku yang bersifat fiksi dan sejarah, namun pesan kekristennya bias sampai ke pembacanya, bahkan mungkin tanpa disadarinya.

James (Jim) Innell Packer yang lebih dikenal dengan sebutan J.I. Packer $(22$ Juli 1926- $\quad \ldots)^{4} \quad$ adalah seorang teolog

Kristen Kanada kelahiranInggris dari gereja Anglikan yang memiliki tradisi Reformed yang sangat kental. Pada tahun 1979, Packer pindah ke Kanada, menjadi Guru Besar atau Profesor Teologi di Regent College di Vancouver, British Columbia, Canada. Dia dianggap salah satu penginjil paling berpengaruh di Amerika Utara. Buku-bukunya telah terjual lebih dari tiga juta kopi di seluruh dunia dan pembaca

${ }^{4}$ Data diolah dari berbagai sumber. 
Christianity Today menamainya sebagai salah satu penulis Kristen dan buku-buku teologi yang paling berpengaruh di abad ke-20, kedua setelah CS Lewis. Bukunya yang paling fenomental, Knowing God telah menjadi salah satu buku best seller yang telah terjual lebih dari sejuta kopi (dan hingga kini masih terus beredar di pasaran) yang telah diterjemahkan ke dalam banyak bahasa di berbagai belahan dunia, termasuk Bahasa Indonesia. ${ }^{5}$ Padahal menurut pengakuannya sendiri, tadinya ia tidak berpikir bahwa buku ini akan laris di pasaran, mengingat bahwa sebenarnya buku tersebut berasal dari kumpulan artikel dwi bulanan yang ditulisnya untuk majalah Evangelical Magazine (sudah tidak terbit lagi) (vii Packer 2011). Packer juga sering menjadi kontributor dan editor majalah Kristen yang sangat berpengaruh, Christianity Today. Selain itu Packer juga menjabat sebagai Editor Umum English Standard Version, sebuah revisi dari kalangan Injili terhadap Versi Alkitab Revised Standard Version, dan Editor untuk Teologi dari The Study Bible Version.

Setelah hijrah ke Kanada, Packer melayani di Gereja Anglikan Van couver St. John, namun akhirnya pada bulanFebruari 2008 memilih untuk meninggalkan Gereja itu karena ketidaksetujuannya terhadap pemberkatan sesame jenis. Tetapi pada bulan Desember 2008, Packer diangkat sebagai kreasionis kehormatan di Katedral St Andrew, Sydney sebagai suatu penghormaatan terhadap dedikasinya dalam masa pelayanan yang sangat panjang sebagai pengajar teologi yang alkitabiah yang setia dan konsisten.

Kini, di usianya yang di atas 90 dia masih bias berkarya dan melayani. Sepanjang hidupnya telah menulis lebih dari 300 buku, jurnal dan artikel serta tulisan-tulisan lain seperti contributor untuk konkordansi dan kamus-kamus teologi. Sebagai seorang Baptis, Packer dalam berpikir dan berteologi berpegang teguh pada teologi Reformed, juga dikenal sebagai seorang Calvinis.

David F. Wells (Lahir tahun1939 di Bulawayo, Rodhesia Selatan (sekarang Zimbabwe) adalah seorang profesor, teolog dan penulis buku yang handal pada akhir abad 20 dan 21dengan minatnya di bidang Budaya, Postmodernisme dan Evangelicalisme. Menjabat sebagai "Distinguished Senior Research Professor" di Gordon Conwell Theological Seminary. Mengenyam pendidikan di University of London, Trinity Evangelical Divinity School, serta Manchester University (untuk gelar Ph.D.). Tulisan yang paling fenomental dan menjadi book

${ }^{5}$ Buku ini pertama kali terbit pada tahun 1973 dan edisi keduanya dilengkapi dengan study guide yang diterbitkan pertama kali tahun 1993. Buku ini telah diterbitkan kedalam Bahasa Indonesia dan menjadi salah satu buku pegangan di banyak sekolah teologi/seminari Kristen. 
seller dan sudah diterjemahkan ke dalam berbagai bahasa (termasuk Bahasa Indonesia_oleh Penerbit Momentum) adalah: No Place for Truth, or Whatever Happened to Evangelical Theology? Yang diterbitkan pertama kali pada tahun 1993 oleh penerbit: William B Eerdmans Publishing Company. Masih puluhan judul buku lainnya yang telah ditulis, di antaranya: Toward a Theology for the Future, (bersama dengan Clark Pinnock (1972); Revolution in Rome (1972); The Evangelicals: What They Believe Who They Are Where They Are Changing, (bersama John Woodbridge, 1975); The Search for Salvation,(1978); The Prophetic Theology of George Tyrrell, (1979); The Person of Christ,(1984); Reformed Theology in America, (1985); God The Evangelist, (1987); Christian Faith and Practice in the Modern World, Grand Rapids: William B Eerdmans Publishing Company, (bersama Mark Noll, (1988), Turning to God, (1989), Tuming to God (republished, 2012); The Gospel in the Modern World (bersama Martyn Eden, 1991); No Place for Truth, or, Whatever Happened to Evangelical Theology, (1993); God in the Wasteland, (1994);The Bleeding of the Evangelical Church, (1995); Losing Our Virtue, (1998); Above All Earthly Pow'rs, (Company, 2005); The Courage to be Protestant, (2008) dan God in the Whirlwind, (2014).

Steven J. Lawson (lahir 13 April 1951). Sebagai senior pastor pada Christ Fellowship Baptist Church di Mobile, Alabama, yang pernah bertugas sebagai pendeta di Arkansas dan Alabama selama dua puluh lima tahun. Dallas Theological Seminary (Th.M.), dan Reformed Theological Seminary (D.Min.). Oleh karena itu meskipun dia berkecimpung dalam pelayanan di kalangan Gereja Baptis, namun semangat, jiwa dan pikirannya sangat dipengaruhi oleh teologi Reformed. Bahkan Dr. Lawson menjadi presiden New Reformation, sebuah pelayanan yang merancang untuk membawa reformasi alkitabiah di gereja hari ini. Dia melayani di Dewan Eksekutif Seminari dan Semangat Guru, mengajarkan khotbah ekspositori di Seminari Guru di program doktor dan mengajar The Expositor's Institute di Grace Community Church.

Banyak buku yang telah ditulisnya, termasuk The Expository Genius of John Calvin; Psalms, Volume I (Mazmur 1-75), Mazmur, Jilid II (Mazmur 76-150), dan Ayub di dalam Seri Komentar Perjanjian Lama; Faith Under Fire, dll. Bukubukunya telah diterjemahkan ke dalam berbagai bahasa di seluruh dunia, termasuk bahasa Rusia, Portugis, Spanyol, dan bahasa Indonesia. Dia telah menyumbangkan beberapa artikel ke Bibliotheca Sacra, The Southern Baptist Journal of Theology, Faith and Mission, Decision Magazine, Discipleship Journal, dan beberapa jurnal serta majalah lainnya. 
Selain banyak menulis, pelayanan mimbar Dr. Lawson juga telah membawanya untuk berkeliling ke seluruh dunia, termasuk ke Rusia, Ukraina, Wales, Inggris, Irlandia, Jerman dengan memberkati ribuan jiwa. Dia juga menghadiri banyak sekali konferensi di seluruh Amerika Serikat dan Luar Negeri. Dr. Lawson juga dikenal sebagai pengisi dan pengkhotbah TV yang bertajuk: The Tributes of God yang memiliki banyak pendengar di seantero Amerika.

\section{Dalam Khotbah dan Penginjilan}

Banyak pengkhotbah terkenal sejak abad pertengahan hingga abad kedua puluh dan dua puluh satu ini yang memiliki pandangan teologi Reformed yang ketat. Meskipun beberapa diantaranya memiliki latar belakang aliran gereja yang bukan reformed. Tapi khotbah-khotbah mereka telah mencerminkan iman dan semangat Reformed sejati yang mengedepankan kebenaran dan kuasa firman Allah.

Jonathan Edwards (5 Oktober 1703 - 22 Maret 1758) adalah seorang teolog dan pendeta asal Amerika Serikat yang sangat memengaruhi peristiwa kebangunan rohani Amerika. Edwards adalah seorang pendeta Kongregasionalis yang banyak membela ajaran Calvinis. Khotbahnya sangat berapi-api dan penuh dengan urapan Roh Kudus. Bahkan ketika dia sedang berkhotbah pada tanggal 8 Juli 1741 yang berjudul Sinners In The Hands of An Angry God (Orang-orang Berdosa Di Tangan Allah Yang Murka), 6 sebelum khotbah ini berakhir, telah banyak orang yang menangis dan berseru-seru, "Apakah yang harus kami perbuat?" sambil berjingkat seolah benar-benar sedang menginjak api neraka. Ribuan orang bertobat setelah mendengarkan khotbah itu. Karena karunianya yang luar biasa itu, Jonathan Edwards disebut sebagai pendeta, pengkhotbah dan misionaris. Pada zamannya, khotbah-khotbahnya sangat dinantikan oleh orang-orang yang rindu akan firmanTuhan.

Dwight Lyman Moody atau D.L. Moody, adalah tokoh kebangunan rohani gelombang ketiga di Amerika Serikat, pada abad ke-19. Ia juga dikenal sebagai pengkhotbah ulung yang sering mengadakan kebangunan rohani. Moody lahir pada tanggal 5 Februari 1837 di Nothfield, Massachusetts dari keluarga petani miskin. Pada tahun 1841, ayahnya meninggal. Karena kemiskinannya dan tanpa ayah, menyebabkan dia keluar dari sekolah ketika masih kelas 5 sekolah

${ }^{6}$ Buku ini juga telah diterbitkan oleh Penerbit Momentum, Surabaya dengan prakata oleh Dr. Stephen Tong. 
dasar. Pada umur 17 tahun, ia pindah ke Boston untuk mencari pekerjaan, namun ia tidak berhasil mendapat pekerjaan, dan akhirnya ia bekerja menjaga toko sepatu milik pamannya, dengan syarat ia harus mengikuti ibadah di Gereja Kongregasional di Boston. Moody kemudian aktif mengikuti Sekolah Minggu dan mengalami pertobatan di gereja ini.

Kemudian pindah ke Chicago dan pada tahun 1860, memutuskan untuk menjadi pekabar injil penuh waktu, meskipun tidak pernah menempuh pendidikan teologi formal. Ia aktif mengadakan kebangunan rohani dan terkenal sebagai seorang pengkhotbah ulung. Dalam pelayanannya dalam rangka kebangunan rohani ia hamper selalu bersama, Ira D. Sankey, seorang penulis dan penggubah lagu yang terkenal. Ia juga aktif dalam organisasi Young Men Christian Association (YMCA), serta dalam gerakan ekumenis lainnya bersama John Mott hingga meninggal pada 22 Desember 1899. Selain jiwa-jiwa yang telah dimenangkannya, peninggalan Moody yang tetap dikenang dan eksis hingga sekarang adalah Moody Bible Institute dan Moody Press. ${ }^{7}$

Charles Haddon Spurgeon (Juni 1834-Januari 1892). Pengkhotbah yang hidup sezaman dengan Moody ini menjadi salah seorang tokoh berpengaruh pada Kebangunan Rohani Inggris dan Eropa abad ke-19. Ia lahir di keluarga pendeta sebuah Gereja Kongregasionalis. Namun Spurgeon baru memutuskan untuk menjadi seorang Kristen pada usia remaja, tahun 1850, dan pada tahun 1852 karena panggilannya, telah menjadi pendeta di sebuah Gereja Baptis di Waterbeach, daerah yang dikenal dengan pemabuknya. Dia dikenal sebagai pengkotbah Baptis yang Reformed, bahkan David J. Hall menyebut bahwa pertobatan Spurgeon itu merupakan suatu ekspresi dari Calvinisme (Hall and Liliback 2009:92) Setelah itu, ia diundang untuk menjadi pendeta di gereja yang lebih besar dengan ribuan orang mendengar khotbah-khotbahnya.

Meskipun Spurgeon sebenarnya bukan seorang yang mempelajari teologi secara formal, namun gaya khotbahnya sederhana namun alkitabiah dan memakai bahasa yang langsung dalam menjelaskan maksudnya, telah banyak menobatkan orang kepada Kristus.

Selain sebagai pengkhotbah yang terkenal, Spurgeon adalah juga seorang penulis yang sangat produktif dengan lebih seratus buku yang telah ditulisnya dan banyak yang sudah diterjemahkan ke dalam berbagai bahasa, di antaranya bahasa: Arab, Armenian, Bengali, Bulgaria, Cina, Kongo, Ceko, Denmark, Belanda, Estonia, Perancis, Gaelik, Jerman, Hindi, Hungaria, Italia , Jepang, Kaffir, Karen,

${ }^{7}$ Data diperoleh dari berbagai sumber. 
Lettish, Maori, Norwegia, Polandia, Rusia, Serbia, Spanyol, Swedia, Syriac, Tamil, Telugu, Urdu, Welsh dan tentu saja, Indonesia. Di antara tulisannya juga telah menulis banyak jilid tentang tafsiran, khotbah-khotbah yang dibukukan, devosi, dan tulisan-tulisan lainnya. Bukunya yang terkenal antara lain: The Power of Prayer in a Believer's Life' Spiritual Welfare in a Believer's Life; A Defense of Calvinism; Holy Spirit; All of Grace, dll.

Billy Graham atau William Franklin Graham (November 1918 November 2014) adalah Penginjil Baptis yang berjiwa Reformed dan berhati Injili. Khotbahnya selalu alkitabiah, meski sederhana. Dia selalu berbicara tentang kasih Allah, dosa dan pengampunan. Selama pelayanannya sudah ribuan kali mengkotbahkan ayat yang sama namun penuh makna, Yohanes 3:16. Billy Graham sangat konsisten dengan ayat yang dibacaya. Konsisten denganfirman Tuhan dan tidak sedikit pun yang berbau menyombongkan dan berpusat pada dirinya. Selama pelayanannya, telah membawa 3,2 jiwa yang dimenangkan bagi Kristus, baik di dalam maupun di luar Amerika. Telah menulis sekitar 30 buah buku, salah satu buku yang terkenal dan sudah diterjemahkan kedalam bahasa Indonesia adalah "Bebas Dari Tujuh Dosa Maut" yang diterjemahkan dan diterbitkan oleh Yayasan Komunikasi Bina Kasih, OMF.

Stephen Tong (lahir 1940 di Xiamen, Fujian, China). Menerima Tuhan Yesus sebagai Juruselamat sejak berusia 3 tahun dan sudah melayani dalam khotbah-khotbah sejak berusia 17 tahun. Dia dikenal sebagai hamba Tuhan yang tegas, keras, serius tetapi humble. Sebagai seorang penganut Reformed fanatik, Stephen Tong telah mendirikan Gereja Reformed Injili Indonesia (GRII) dan bersama dengan Yakub Susabda mendirikan Sekolah Tinggi Toleogi Reformed Injili Indonesia (STRII), yang belakangan setelah Yakub Susabda menjadi Rektor nama itu diganti menjadi Sekolah Tinggi Teologi Reformed Indonesia (STTRI). Tak dapat disangkal bahwa Stephen Tong adalah Pendeta yang paling terkenal di Indonesia, khususnya di kalangan kaum Injili dan Reformed. Telah berkhotbah puluhan ribu kali di seluruh Indonesia dan dunia. Selain berkhotbah, Dr. Tong juga mengajar di beberapa sekolah teologi, seperti SAAT Malang dan STTRI(I) serta beberapa seminari di luar negeri. Setiap tahun juga memimpin berbagai seminar teologi di kota-kota besar di Indonesia dan kota-kota lainnya di luar negeri. Berbeda dengan para pengkhotbah KKR lainnya yang kebanyakan berisi tentang berkat, kehidupan yang melimpah, kepedulian Allah, dsb., hamper semua khotbah Dr. Tong berisi doktrin-doktrin tentang iman Kristen, dosa dan keselamatan, hidup kekal, penginjilan, tanggung jawab orang Kristen dan sebagainya. 
Karena sikap tegas dan kerasnya dalam hal doktrin yang diyakininya, seringkali membuat orang-orang dan hamba Tuhan lainnya "tidak menyukainya". Namun keteguhannya dalam memertahankan dan mengajarkan doktrin-doktrin Reformed yang diyakininya, membuat para "pengikut" dan jemaatnya menjadi orang-orang Kristen yang "militan."

Dr. Tong juga banyak menulis buku yang sebagian besar adalah transkrip dari khotbah atau seminar dan diskusi-diskusi ilmiah-teologinya. Dia adalah hamba Tuhan dengan multi talenta (pengkhotbah, dosen seminari, musik dan arsitek secara otodidak). Membangun dengan desainnya sendiri Messias Cathedral dengan gedung konsernya yang bertaraf internasional di Kemayoran, Jakarta, di mana Pak Tong juga menjadi konduktor dan pendiri Jakarta Oratorio Society (JOS) dengan konser dan lagu-lagu klasiknya. Melalui pelayanannya di berbagai benua, dengan jiwa dan semangat Reformednya telah dibawa kepada Tuhan ribuan orang yang mengalami pertobatan dan hidup baru, dan banyak di antaranya menjadi hamba Tuhan.

Ciri-ciri khotbah Reformed

Para pengkhotbah Reformed (dan Injili) umumnya khotbahnya lebih banyak bersifat doktrin yang membangun dan menguatkan iman jemaat, penginjilan, hidup berkemenangan, dosa dan penghukuman, penebusan, keselamatan dan pengudusan. Jarang berbicara tentang hal-hal yang bersifat kehidupan praktis dalam kehidupan sehari-hari seperti kesembuhan, pergumulan hidup, berkat-berkat jasmani, dsb.

\section{PENGARUH DALAM BIDANG-BIDANG LAINNYA}

Sesungguhnya "roh" reformasi telah berpengaruh luas terhadap berbagai bidang pelayanan. Selain yang telah disebutkan di atas, jiwa Reformed-secara langsung maupun tidak langsung-telah menjadi darah segar yang membakar semangat gerakan misi. Nama-nama seperti: David Livingstone, William Carey, Hudson Taylor, bahkan John Sung, dan sebagainya adalah para misionaris atau pekabar Injil yang hatinya ditantang untuk menyampaikan kebenaran firman dan Injil Yesus Kristus kepada orang-orang yang belum percaya dalam rangka memenuhi panggilan agung TuhanYesus dalam Matius 28:19-20.

Di bidang pendidikan teologi, jelas dengan adanya seminari-seminari semacam Reformed Theological Seminary (RTS); Calvin Theological Seminary 
(CTS); Princeton Theological Seminary (PTS); International Theological Seminary (ITS) dan di Indonesia Sekolah Tinggi Teologi Reformed Indonesia (STTRI) adalah jelas-jelas sekolah teologi yang berlabel Reformed. Sehingga beberapa sekolah teologi lainnya di Indonesia yang semula dikenal dengan sekolah Injili, lama-kelamaan juga pada melabelkan sebagai sekolah teologi yang mendasarkan pengajarannya pada teologi Reformed atau Reformed Injili, seperti halnya STT SAAT, STTB, STTAA, ST'T IMAN dan sebagainya.

Demikian pula dengan gereja-gereja yang sekarang bertumbuh subur di berbagai tempat dengan label aliran Reformed, Injili atau Calvinis, menyatakan bahwa ada kerinduan gereja-gereja untuk "kembali kepada Alkitab," Back To the Bible, kembali kepada pengajaran yang murni, reformasi.

\section{KESIMPULAN}

Secara sederhana, bagi penulis sebenarnya setiap pengajaran dan pandangan teologi, apa pun alirannya, yang penting setia pada tri sola, serta pengakuan iman seperti yang tertuang dalam pengakuan-pengakuan iman: Belgic Confession (1561); Heidelberg Cathecism (1563); The Canons of Dort (1619) maupun The Westminster Confession of Faith (1649) berartidia adalah Reformed. Reformed harus Injili dan Injili harus Reformed. Jadi, baik itu yang mengklaim diri sebagai Reformed, Injili, Reformed Injili-bahkan dua tahun ini sudah mulai muncul aliran dengan label Reformed Kharismatik-asal setia pada pengajaran danisi Alkitab secara murni, hanya pada Sola Gratia, Sola Fide, Sola Scriptura, Solus Christus Soli Deo Gloria, menurut hemat penulis, semuanya bias disebut sebagai kaum Reformed, yang Back To The Bible, Back To Basic. Itulah Reformed yang sebenarnya.

\section{DAFTAR PUSTAKA}

Baan, G. J. 2009. TULIP: Lima Pokok Calvinisme. Surabaya: Momentum.

Bavinck, Herman. 2014. Dogmatika Reformed. Surabaya: Momentum.

Boettner, Loraine. 1932. The Reformed Doctrine of Predestination. New Jersey: Presbyterian and Reformed.

Boice, James Montgomery. 1993. Foundation of the Christian Faith: A Comprehensive \& Readable Theology. Downers Grove: InterVarsity Press.

Calvin, Yohanes. 2015. Institutio. Jakarta: BPK Gunung Mulia. 
Hall, David WS, and Peter A. Liliback. 2009. Penuntun Ke Dalam Teologi Institutes Calvin (Terj.). Surabaya: Momentum.

Hoekema, Anthony. 2009. Diselamatkan Oleh Anugrah (Terj.). Surabaya: Momentum.

Meeter, M. Jenry. 2009. Pandangan-Pandangan Dasar Calvinisme (Terj.). Surabaya: Momentum.

Packer, J. I. 2011. Mengenal Allah (Terj.). Yogyakarta: ANDI.

Susabda, Yakub. 2001. Pengantar Ke Dalam Teologi Reformed. Surabaya: Momentum.

Wells, David F. 2014. Kebenaran Menjadi Protestan (Terj.). Surabaya: Momentum. 